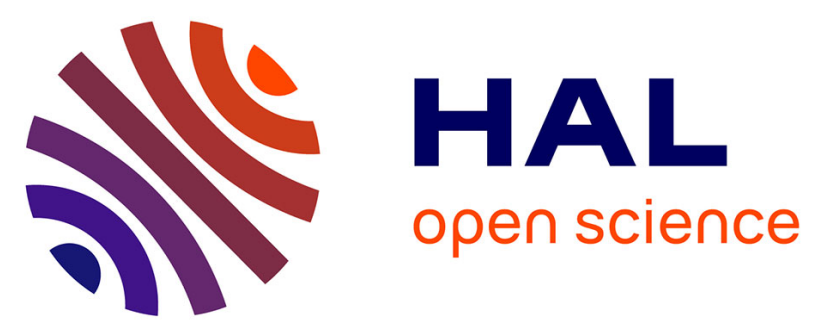

\title{
Role of Serum and Glucocorticoid-Regulated Kinase-1 in the protective effects of erythropoietin during renal ischemia/reperfusion injury
}

Krisztina Rusai, Ágnes Prókai, Beáta Szebeni, Andrea Fekete, András Treszl, Ádám Vannay, Veronika Müller, György Reusz, Uwe Heemann, Jens Lutz, et al.

\section{To cite this version:}

Krisztina Rusai, Ágnes Prókai, Beáta Szebeni, Andrea Fekete, András Treszl, et al.. Role of Serum and Glucocorticoid-Regulated Kinase-1 in the protective effects of erythropoietin during renal ischemia/reperfusion injury. Biochemical Pharmacology, 2010, 79 (8), pp.1173. 10.1016/j.bcp.2009.11.022 . hal-00565095

\section{HAL Id: hal-00565095 https://hal.science/hal-00565095}

Submitted on 11 Feb 2011

HAL is a multi-disciplinary open access archive for the deposit and dissemination of scientific research documents, whether they are published or not. The documents may come from teaching and research institutions in France or abroad, or from public or private research centers.
L'archive ouverte pluridisciplinaire HAL, est destinée au dépôt et à la diffusion de documents scientifiques de niveau recherche, publiés ou non, émanant des établissements d'enseignement et de recherche français ou étrangers, des laboratoires publics ou privés. 


\section{Accepted Manuscript}

Title: Role of Serum and Glucocorticoid-Regulated Kinase-1 in the protective effects of erythropoietin during renal ischemia/reperfusion injury

Authors: Krisztina Rusai, Ágnes Prókai, Beáta Szebeni, Andrea Fekete, András Treszl, Ádám Vannay, Veronika

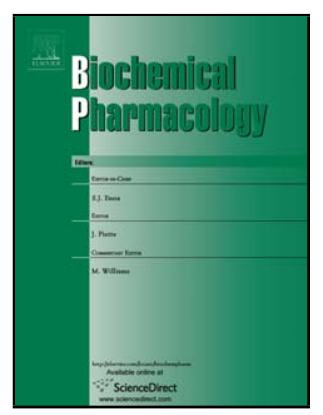

Müller, György Reusz, Uwe Heemann, Jens Lutz, Tivadar

Tulassay, Attila J. Szabó

PII: $\quad$ S0006-2952(09)01034-X

DOI: $\quad$ doi:10.1016/j.bcp.2009.11.022

Reference: $\quad$ BCP 10394

To appear in: $\quad B C P$

Received date: $\quad 20-10-2009$

Revised date: 23-11-2009

Accepted date: $\quad$ 24-11-2009

Please cite this article as: Rusai K, Prókai Á, Szebeni B, Fekete A, Treszl A, Vannay Á, Müller V, Reusz G, Heemann U, Lutz J, Tulassay T, Szabó AJ, Role of Serum and Glucocorticoid-Regulated Kinase-1 in the protective effects of erythropoietin during renal ischemia/reperfusion injury, Biochemical Pharmacology (2008), doi:10.1016/j.bcp.2009.11.022

This is a PDF file of an unedited manuscript that has been accepted for publication. As a service to our customers we are providing this early version of the manuscript. The manuscript will undergo copyediting, typesetting, and review of the resulting proof before it is published in its final form. Please note that during the production process errors may be discovered which could affect the content, and all legal disclaimers that apply to the journal pertain. 


\title{
Role of Serum and Glucocorticoid-Regulated Kinase-1 in the protective effects of erythropoietin during renal ischemia/reperfusion injury
}

\author{
${ }^{1}$ Krisztina Rusai, ${ }^{1}$ Ágnes Prókai, ${ }^{1}$ Beáta Szebeni, ${ }^{1}$ Andrea Fekete, ${ }^{1}$ András Treszl, ${ }^{1}$ Ádám Vannay, \\ ${ }^{2}$ Veronika Müller, ${ }^{1}$ György Reusz, ${ }^{3}$ Uwe Heemann, ${ }^{3}$ Jens Lutz, ${ }^{1}$ Tivadar Tulassay, ${ }^{1}$ Attila J. Szabó \\ ${ }^{1}$ First Department of Pediatrics, Semmelweis University, 1083 Budapest, Bókay u. 53-54. Hungary \\ ${ }^{2}$ Department of Pulmology, Semmelweis University, 1125 Budapest, Diósárok u. 1c. Hungary \\ ${ }^{3}$ Department of Nephrology, Klinikum rechts der Isar, 81675 Munich, Ismaninger Str. 22. Germany
}

Running title: EPO and SGK1 in ischemia/reperfusion injury

\section{Corresponding Author:}

Krisztina Rusai MD, PhD

First Department of Pediatrics, Semmelweis University

Budapest, Bókay utca 53-54. 1083 Hungary

Email: rusai@gyer1.sote.hu

Phone/Fax: +36-1-3343186/52697 


\section{ABSTRACT}

Erythropoietin (EPO) protects the kidneys from ischemia/reperfusion (I/R) injury; however, the exact signalling mechanisms are not fully understood. The serum and glucocorticoid-regulated kinase 1 (SGK1) is an anti-apoptotic protein kinase regulated through the phosphatidylinositol 3kinase (PI3-kinase) pathway by cellular stimuli, hormones and growth factors. The objective of the present study was to examine the role of SGK1 in the renoprotective effects of EPO in renal I/R injury.

In vitro, cultures of HEK293 cells were exposed to $16 \mathrm{~h}$ hypoxia. Incubation with EPO at a dosis of $400 \mathrm{U} / \mathrm{ml}$ exerted a protective effect on cell death assessed by LDH release and Annexin-V FACS analysis. This was paralleled by up-regulation of SGK1 expression, as well as phosphorylation. Downregulation of SGK1 expression by small interfering RNA technique ameliorated the antiapoptotic effect of EPO treatment.

In an in vivo rat model of unilateral renal I/R injury, rats were treated with $500 \mathrm{U} / \mathrm{kg}$ EPO $24 \mathrm{~h}$ prior to ischemia. EPO resulted in less severe tissue injury and ameliorated the elevation in creatinine and urea nitrogen levels $24 \mathrm{~h}$ after reperfusion. Furthermore, SGK1 expression and phosphorylation were higher in EPO compared to vehicle treated rats as demonstrated by real-time PCR, Western blot and immunofluorescence technique.

We conclude that EPO protects from renal I/R injury and SGK1 might contribute to the mediation of EPO effects under ischemic conditions.

Keywords: EPO, apoptosis, hypoxia, ischemia/reperfusion, kidney, SGK1 


\section{INTRODUCTION}

Erythropoietin (EPO) is a glycoprotein hormone primarily responsible for the regulation of red blood cell production [1]. However, increasing evidence suggests that independently of its erythropoietic effects, it also exerts protective actions against ischemic injury in various organs [2].

EPO is up-regulated in brain, spinal cord and kidney after hypoxic stimuli and it protects the cells from apoptosis $[3,4,5]$. Furthermore, exogenous EPO administration after renal ischemia/reperfusion (I/R) injury has also been demonstrated to ameliorate tissue injury mainly by preventing apoptotic cell death [5,6,7 ]. I/R injury is among the leading causes of morbidity and mortality in various diseases including acute renal failure, heart failure, stroke and post-transplant graft dysfunction. The balance between the activation of pro- and anti-apoptotic pathways in the post-ischemic tissue plays a critical role in ischemia-induced organ dysfunction as apoptotic cell death has been recognized as a major mode of cell demise in I/R injury [8].

EPO exerts its immediate anti-apoptotic effects via an activation of multiple signalling pathways of which phosphorylation and activation of the phosphatidylinositol 3-kinase (PI3-kinase) [9] and signal transducer and activator of transcription 3 (STAT3) kinase [10] seem to play pivotal roles. However, the underlying mechanisms have still not been fully described and possibly, additional pathways are involved in the protective effects of EPO.

Activation of the PI3-kinase induces to the phosphorylation of protein kinase B (Akt). Akt has multiple effects on cell survival by directly maintaining mitochondrial integrity and through the inhibition of several pro-apoptotic mediators [11]. The serum- and glucocorticoid-inducible protein kinase 1 (SGK1) is a serine-threonine kinase which is $50-55 \%$ homologue to Akt. SGK1 is also directly phosphorylated and, thus activated by the phosphoinositide-dependent kinase 1 (PDK1) which acts in a PI3-kinase-dependent manner [12] and share a number of common target molecules [13].

The expression and activation of SGK1 is increased by various cell stress stimuli such as hyperosmotic stress, ultraviolet radiation, heat shock [14], oxidative stress [15] and hypoxia [16]. Under these conditions SGK1 acts as a strong anti-apoptotic kinase mainly by phosphorylating FKHRL1 and IKK $\beta$ [18].

Recently, we have shown that SGK1 is up-regulated and exerts anti-apoptotic effects after renal I/R injury in kidney-derived tubular cells and in the kidney tissue (manuscript accepted in Cell Physiol Biochem).

Since the protective effects of EPO are mediated mainly by the PI3-kinase pathway and SGK1 seems to be one of the main downstream targets of this pathway, we hypothesized that the anti-apoptotic effects of EPO during ischemic renal injury might be mediated by the PI3-kinase regulated SGK1. 
Therefore, we investigated the effects of EPO administration on SGK1 expression and activation during renal I/R injury both under in vitro and in vivo conditions. Furthermore, we inhibited SGK1 through small interfering technique to further study the direct impact of SGK1 on the EPO action. 


\section{METHODS AND MATERIALS}

\section{Reagents}

Human recombinant EPO epoetin beta and placebo were obtained from Roche Hungary (Budaörs, Hungary).

\section{Cell culture}

The human embryonic kidney (HEK) 293 cell line derived from human embryonic kidney cells was purchased from American Type Culture Collection (ATCC, Rockville, MD). All cells were cultured in Dulbecco's Modified Eagle Medium (DMEM) supplemented with 10\% heat inactivated fetal bovine serum (FBS) (PAN Biotech $\mathrm{GmbH}$, Aidenbach, Germany) and were propagated at $37^{\circ} \mathrm{C}$ in a humidified air containing $5 \% \mathrm{CO}_{2}$ incubator.

\section{In vitro hypoxia model}

HEK 293 cells were seeded out and plated on 6-well plates at $5 \times 10^{5} / \mathrm{ml} 24 \mathrm{~h}$ prior to the induction of hypoxia.

For hypoxia the medium was changed to serum- and glucose-free DMEM saturated with 95\% $\mathrm{N}_{2} / 5 \%$ $\mathrm{CO}_{2}$ and cells were placed in a $37^{\circ} \mathrm{C}$ airtight box for $16 \mathrm{~h}$. For normoxic conditions, culture medium was changed to serum- and glucose-free DMEM and cells were placed in a $37{ }^{\circ} \mathrm{C} / 5 \% \mathrm{CO}_{2}$ incubator for $16 \mathrm{~h}$. After $16 \mathrm{~h}$ of incubation time cells were analyzed.

Human recombinant EPO epoetin beta was obtained from Roche Hungary (Budapest, Hungary) and was added to the cell culture medium in a final concentration of $400 \mathrm{U} / \mathrm{ml} 2 \mathrm{~h}$ prior to the induction of hypoxia or to control normoxic cells. Placebo solution, also obtained from Roche Hungary served as vehicle control.

\section{Annexin V Analysis}

Annexin V-propidium-iodid (PI) apoptosis kit was used according to the manufacturer's protocol to detect apoptosis in vitro (Caltag Laboratories, Karlsruhe, Germany). In brief, cells were washed with phosphate buffered saline (PBS) and stained with Fluorescein labelled Annexin V and PI and then analyzed by flow cytometry. Annexin V and PI positive cells were considered as apoptotic cells.

\section{SGK-1 gene silencing}

For sgk-1 gene silencing small interfering RNA (siRNA) technique was used. Sgk-1-specific target sequence (5'- AAUGUGAAGCACCCUUUCCUG -3'), was annealed and cloned into pSilencer-4.1$\mathrm{CMV}-\mathrm{Neo}$ (Ambion) at BamHI-HindIII sites according to the manufacturer's instructions. 
To knock down Sgk1 expression, HEK293 cells were transfected with Sgk1-specific RNAi constructs and were examined $48 \mathrm{~h}$ after transfection. The pSilencer-4.1-CMV-Neo negative control construct was transfected similarly and used as a negative control.

\section{In vivo renal $\mathrm{I} / \mathrm{R}$ model}

\section{Animals and surgery}

Male Wistar rats (weighing 250-275 g) were subjected to $50 \mathrm{mg} / \mathrm{kg}$ pentobarbital sodium anaesthesia (Nembutal, Abbott Laboratories, Budapest, Hungary) and the abdomen was opened through a midline incision left renal artery and vein were clipped by an atraumatic vascular clamp for $50 \mathrm{~min}$ during which right nephrectomy was performed. After $50 \mathrm{~min}$ of ischemia, the clamp was removed and the animals were allowed to recover. After $2 \mathrm{~h}$ and $24 \mathrm{~h}$ of reperfusion, rats were reanaesthetized and the remnant kidney was removed.

EPO treated rats were given $500 \mathrm{U} / \mathrm{kg}$ EPO Roche Hungary (Budapest, Hungary) intraperiotenally, $24 \mathrm{~h}$ prior to ischemia and animals were randomized into the following groups (1) sham + vehicle, (2) sham + EPO, (3) I/R $2 \mathrm{~h}+$ vehicle, (4) I/R 2h + EPO, (5) I/R 24h + vehicle and (6) I/R 24h + EPO. Sham-operated rats (groups 1 and 2) underwent identical surgical procedures without unilateral renal clamping and were maintained under anaesthesia for the duration of the experiment $(N=8 /$ each group).

All animal experiments were approved by the Ethical Committee of the Semmelweis University.

\section{Lactate dehydrogenase (LDH) and renal function parameters}

LDH release into the cell supernatant, serum creatinine and blood urea nitrogen (BUN) levels were analyzed by an automatic laboratory analyzer (Synchron CX5, Beckman Coulter, Krefeld, Germany). LDH results are expressed as a percentage of total cellular LDH per well measured from cells lysed in $1 \%$ Triton-X 100 and corrected with appropriate media controls and total protein.

\section{Renal histopathology}

Paraffin sections of kidneys fixed in $4 \%$ neutral buffered formalin were stained with hematoxylin and eosin (H\&E) and with periodic acid-Schiff (PAS) reagent. Histological changes typical to I/R injury such as tubular architecture, tubular dilation, swelling and necrosis, luminal congestion with loss of brush border, interstitial edema and infiltration of polymorphonuclear neutrophils were semiquantitatively evaluated and scored. Two independent observers examined the slides by light microscopy in a blinded fashion. 


\section{Reverse transcription-polymerase chain reaction (RT-PCR)}

Human SGK1 mRNA expression in HEK293 cells were determined by RT-PCR analysis. Total RNA was isolated from the cells by RNeasy Total RNA Isolations Kit (Qiagen GmbH, Hilden, Germany) according to the instructions of the manufacturer. The quality and quantity of the RNA were confirmed photometrically. (17)

After initial denaturation at $94^{\circ} \mathrm{C}, 35$ cycles of amplification at the accurate annealing temperature for human SGK1 and Glyceraldehyde 3-phosphate dehydrogenase (GAPDH) were performed. The primer sequences and annealing temperatures are shown in Table 1. PCR products were separated on ethidium-bromide stained $2.5 \%$ agarose gels, then visualized and photographed under ultraviolet light.

Signals were quantified by densitometry and corrected for the GAPDH signal using an image analysis software program (Gel-Pro Analyser 3.1 Software).

\section{Real-time polymerase chain reaction}

Rat SGK1 mRNA expression in the renal tissues was assessed by SYBR Green real-time PCR on a Light Cycler system (Roche Diagnostics, Mannheim, Germany). PCRs were performed in glass capillaries, in a final volume of $20 \mu \mathrm{l}$ containing $3 \mathrm{mM} \mathrm{MgCl}_{2}, 0.2 \mu \mathrm{M}$ of each primer, $2 \mu \mathrm{l}$ LightCycler FastStart DNA Master SYBR Green I (Roche Diagnostics, Mannheim, Germany) and 1 $\mu \mathrm{l}$ of cDNA. The conditions of PCRs were as follows: one cycle at $95^{\circ} \mathrm{C}$ for $8 \mathrm{~min}$, followed by 55 cycles at $95^{\circ} \mathrm{C}$ for $3 \mathrm{~s}, 59^{\circ} \mathrm{C}$ for $5 \mathrm{~s}$ and $72{ }^{\circ} \mathrm{C}$ for $28 \mathrm{~s}$ with a single fluorescence detection point at the end of the extension.

mRNA expression of GAPDH in tissue samples was determined by real-time PCR quantification using fluorescence resonance energy transfer (FRET) hybridization probes on a Light Cycler system (Roche Diagnostics, Mannheim, Germany) in a final volume of $20 \mu \mathrm{l}$ containing $2 \mathrm{mM} \mathrm{MgCl}_{2}, 0.17$ $\mathrm{nM}$ of each hybridization probe, $0.5 \mathrm{nM}$ of each primer, $2 \mu \mathrm{l}$ of the Light-Cycler FastStart DNA Master HybProbe (Roche Diagnostics) and $1 \mu \mathrm{l}$ of cDNA. The PCR reaction was carried out under the following conditions: one cycle at $95^{\circ} \mathrm{C}$ for $8 \mathrm{~min}$, followed by 50 cycles at $95^{\circ} \mathrm{C}$ for $4 \mathrm{~s}, 55^{\circ} \mathrm{C}$ for $8 \mathrm{~s}$ and $72^{\circ} \mathrm{C}$ for $22 \mathrm{~s}$ with a single fluorescence detection point at the end of the annealing segment.

\section{Western blotting}

Cells and kidney tissues were homogenized by a cell disrupter in chilled lysis buffer containing 1 $\mathrm{mg} / \mathrm{mL}$ aprotinine, $5 \mathrm{mg} / \mathrm{mL}$ leupeptin, $1 \mathrm{M}$ Tris, 0.5 M EGTA, 0.25 M NaF, 0.5 M PMSF, 0.5 M 
$\mathrm{Na}_{3} \mathrm{VO}_{4}$ and $0.1 \%$ Triton $\mathrm{X}-100$. The lysate was centrifuged at $13.000 \mathrm{~g}$ for $10 \mathrm{~min}$ to remove insoluble debris. Protein concentrations in the supernatant were determined by the Bradford method using BSA as standard. All reagents for PAGE and Western blot were purchased from Sigma Aldrich (Munich, Germany). Lysates were solubilized in a buffer of $12.5 \mathrm{mM}$ Tris-HCl, $\mathrm{pH}$ 6.7, containing $4.0 \%$ SDS, $1 \mathrm{mM}$ EDTA, $15 \%$ glycerol and $0.01 \%$ bromphenolblue. $50 \mu \mathrm{g}$ protein of the samples was separated on 10\% SDS-polyacrylamide gel and transferred to nitrocellulose membranes (Amersham, GE Healthcare Europe GmbH, Munich, Germany). The membranes were blocked with $5 \%$ non-fat dry milk (NFDM) for $1 \mathrm{~h}$ at room temperature and then probed with rabbit polyclonal anti-SGK1 antibody (1:400, Upstate, Germany) in 5\% NFDM overnight at $4{ }^{\circ} \mathrm{C}$. The membranes were washed with Tween-phosphate-buffered saline, and incubated with anti-rabbit immunoglobuline antibody, a horseradish peroxidase conjugated from goat (1:5000, Amersham) in 5\% NFDM for $1 \mathrm{~h}$ at room temperature. Proteins were detected by enhanced chemiluminescence (ECL, Amersham) by Kodak Image Station 400 D. Prestained standards were used as molecular weight markers (Biorad Laboratories, Munich, Germany).

Signals on Western blots were quantified by densitometry using Gel-Pro Analyser 3.1 Software.

\section{Double labeling using immunofluorescence microscopy}

Kidney sections were immediately snap-frozen in $30 \%$ sucrose for immunohistochemical analysis. They were embedded in Shandon cryomatrix (ThermoElectron Co.), cut into 5-10 $\mu \mathrm{m}$ thick slices with a cryostat, and stored at $-80^{\circ} \mathrm{C}$. After rinsing in PBS, they were treated in methanolic $\mathrm{H}_{2} \mathrm{O}_{2}$ for 30 min. Tissue sections were permeabilized in $0.2 \%$ Triton X-100 in PBS and then blocked in $0.5 \%$ NFDM for $30 \mathrm{~min}$ at room temperature. The samples were incubated overnight at $4{ }^{\circ} \mathrm{C}$ with primary antibodies (anti-total SGK 1:100, Santa Cruz, anti-phospho-SGK1 1:100, Cell Signaling), washed with PBS, and then incubated with secondary antibodies (Alexa Fluor 488 1:100, Alexa Fluor 546 1:100, Invitrogen, Budapest, Hungary) for $30 \mathrm{~min}$ at room temperature. DNA was stained with Hoechst 33342 (1:1000 Sigma, Hungary) for $10 \mathrm{~min}$ at room temperature. Appropriate controls were performed omitting the primary antibodies to ensure their specificity and to avoid auto-fluorescence. Stained slides were analysed in a blinded fashion, localisation and expression of SGK1 was detected.

\section{Statistical analysis}

Data are expressed as mean \pm standard deviation (SD). Data were tested using the Chi-Square- or Mann-Whitney U test using the SPSS statistical software package (v. 13.0, SPSS GmbH, Munich, Germany). Data were analyzed using one-way ANOVA followed by Dunnett post hoc test or Kruskal-Wallis ANOVA for nonparametric data. $P<0.05$ was considered significant. 


\section{RESULTS}

\section{In vitro experiments}

EPO prevents apoptosis after hypoxia in HEK 293 cells

Exposure of HEK293 cells to 24 h hypoxia caused significant cell death when compared to normoxic cells detected by LDH release into the supernatant $(P<0.01)$. In particular, apoptosis of cells caused by hypoxia was demonstrated by Annexin V FACS analysis and proved to be elevated in comparison to normoxic cells $(P<0.01)$ (Figure 1A-B.). Hypoxia-induced overall cell death and also specifically, apoptosis were reduced by incubation with EPO $(400 \mathrm{U} / \mathrm{ml})$ compared to vehicle treated cells $(P<0.01)$ (Figure 1A-B.).

\section{EPO stimulates the expression and phosphorylation of SGK1}

Incubation of HEK293 cells with EPO increased SGK1 mRNA and protein expression both under normoxic and hypoxic conditions $(P<0.01$ vs. vehicle treated cells). Hypoxia stimulated phosphorylation of SGK1 ( $P<0.01$ vs. vehicle treated cells, respectively) which was further increased by EPO ( $P<0.01$ vs. vehicle treated cells) (Figure 2A-B.).

The effect of SGK1 siRNA on the anti-apoptotic action of EPO in hypoxia

To further examine the role of SGK1 in the mediation of EPO actions, we inhibited SGK1 expression by plasmid-mediated siRNA technique. Cells in which SGK1 expression was inhibited showed reduced protection after EPO treatment in hypoxic injury detected by LDH release and Annexin V FACS analysis (both $P<0.01$ ) (Figure 1A-B.).

\section{In vivo experiments}

Effect of EPO on renal dysfunction and post-ischemic structural damage caused by $I / R$

Administration of EPO to sham-operated animals did not have any effect on renal function (Figure 3A-B.).

Renal I/R injury increased post-ischemic serum creatinine and BUN levels $24 \mathrm{~h}$ after repefusion (both $P<0.001$ vs. sham) (Figure 3A-B., Table 2.). In the earlier time-point, $2 \mathrm{~h}$ after reperfusion, no significant elevation in serum renal function parameters were detected. A single bolus of EPO (500 $\mathrm{U} / \mathrm{kg}$ ) resulted in lower levels of serum creatinine and BUN at $24 \mathrm{~h}$ after reperfusion compared to vehicle treated animals $(P<0.01)$ (Figure 3A-B.).

Renal I/R injury caused marked alterations in renal histology compared with kidneys taken from sham-operated animals (Figure 4A.). At $2 \mathrm{~h}$ of reperfusion, in contrast to the renal function parameters, there were already changes in the kidney tissue compared to sham operated animals: 
kidney tissue was oedemic, swelling and blebbing of tubular cells were detected, but no difference was demonstrated between the vehicle and EPO group.

Parallel to the marked elevation in renal function parameters, $24 \mathrm{~h}$ after reperfusion, widespread degeneration of tubular architecture was detected. Both apoptosis and necrosis of tubular cells were observed. Apoptotic tubular cells had chromatin condensation, pyknosis, and karyorrhexis in the nucleus leading to cytoplasmic condensation triggering the cell to shrink and form numerous vacuoles within the cytoplasm. Necrosis of tubular cells were characterized by chromatin flocculation, swelling and degeneration of the entire cytoplasm and the mitochondrial matrix, blebbing of the plasma membrane, and eventual shedding of the cytoplasmic contents into the extracellular space. Necrosis and apoptosis of tubular cells result in tubular atrophy and loss of brush borders (Figure 4A.). $24 \mathrm{~h}$ after reperfusion renal sections of EPO treated animals demonstrated a reduction of the histological features of renal injury such as markedly less tubular necrosis and apoptosis resulting in significantly less atrophy and infiltration of leukocytes compared to vehicletreated rats $(P<0.01)$ (Figure 4A-B.).

\section{Effect of EPO on SGK1 expression and phosphorylation in renal I/R injury}

Administration of EPO resulted in a higher SGK1 mRNA expression at all time-points compared to vehicle treated animals ( $P<0.01$ vs. shams, $2 \mathrm{~h}, 24 \mathrm{~h}$, respectively) (Figure 5A.). EPO treatment led to the highest elevation in SGK1 mRNA expression in sham-operated animals.

SGK1 mRNA expression was temporarily elevated $2 \mathrm{~h}$ after reperfusion $(P<0.05$ vs. sham) (Figure $5 \mathrm{~A}$.), but at $24 \mathrm{~h}$ of reperfusion, it returned to the level of sham-operated rats. Similarly to the vehicle-treated rats, in EPO-treated animals SGK1 mRNA expression decreased $24 \mathrm{~h}$ after reperfusion compared to the $2 \mathrm{~h}+\mathrm{EPO}$ rats $(P<0.05)$ (Figure $5 \mathrm{~A}$.).

Parallel to the changes in mRNA expression, EPO treatment resulted in markedly elevated SGK1 protein levels compared to the vehicle-treated rats both in sham-operated and in IR $2 \mathrm{~h}$ animals $(P<0.01$ respectively), however, $24 \mathrm{~h}$ after reperfusion, no difference was detected $(P>0.05)$ (Figure 5B.).

The activated phosphorylated form of SGK1 was detectable only $2 \mathrm{~h}$ after reperfusion in the vehicletreated animals. On the contrary, in the EPO treated rats, SGK1 phoshorylation was detectable already in the sham-operated animals and it was higher in the $2 \mathrm{~h}$ IR group $(P<0.01$ vs. vehicletreated rat) (Figure 5B.).

To show the location of SGK1 and phosphorylated SGK1, we performed immunofluorescent (IF) staining of the kidneys. IF demonstrated that SGK1 was expressed in the tubular cells. In accordance with the Western blot measurements EPO treatment up-regulated total and phosphorylated SGK1 in 
sham-operated and in $2 \mathrm{~h}$ IR animals, whereas $24 \mathrm{~h}$ after reperfusion, no major difference was seen as compared to the vehicle-treated rats. 


\section{DISCUSSION}

The glycoprotein hormone EPO, which is mainly responsible for the regulation of erythropoesis, seems to also have strong anti-apoptotic effects under hypoxic and oxidative stress, both main features of an in vivo I/R injury. In the present study, we investigated the role of SGK1 in the renoprotective effects of EPO during renal I/R injury.

In our experiments, EPO protected both cultured kidney cells and also the kidney tissue against hypoxic and ischemic injury. HEK293 cells treated with $400 \mathrm{U} / \mathrm{mL}$ recombinant EPO were protected from cell death caused by $16 \mathrm{~h}$ of hypoxia. Furthermore, in a rat model of renal I/R injury, EPO treatment $(500 \mathrm{U} / \mathrm{kg}) 24 \mathrm{~h}$ prior to the induction of ischemia improved post-ischemic renal function and diminished renal structural damage.

These results are well in accordance with earlier observations providing convincing evidence for a protective role of EPO. Yang et al. were the first to demonstrate that a high-dose of EPO (3000 $\mathrm{U} / \mathrm{kg}$ ) $24 \mathrm{~h}$ before bilateral renal artery clamping protected the kidneys from ischemic injury. At $24 \mathrm{~h}$ post-reperfusion, both the rise in creatinine level and the apoptosis of proximal tubular epithelial cells were attenuated in EPO treated animals [18].

Moreover, Sharples et al. presented that EPO in a lower dose (300 U/kg) protected the kidney against unilateral I/R injury when even given as late as $30 \mathrm{~min}$ after the onset of reperfusion [5]. As they did not detect any renal hemodynamic effects, and the EPO receptor is known to be expressed in renal tubular epithelial cells they also proposed a direct of EPO on proximal tubular epithelial cells and protects them from hypoxia-induced apoptosis. These findings are backed up by Huang et al. who found no effect on cortical and papillary perfusion in normal rats after acute EPO administration either [19]. Furthermore, in a model of unilateral ureteral obstruction leading to tubular apoptosis and tubulointerstitial fibrosis, EPO administration directly attenuated the apoptosis of tubular cells and the extent of fibrotic expansion [20].

All these data further support our findings, that EPO in vitro could directly reduce the rate of apoptosis of HEK293 cells after a hypoxic insult, however the exact molecular mechanisms has not been clearly elucidated until recently.

SGK1 which is ubiquitously expressed and induced by stress and hormones (including gluco- and mineralocorticoids, insulin) [18] activates ion channels, carriers and also the Na+-K+-ATPase. It regulates the activity of enzymes and transcription factors (e.g., FKHRL1, NF- $\mathrm{B}$ ) and thus, participates mainly in the regulation of cell proliferation, apoptosis, ion transport and hormone release [21].

In our experiments, hypoxia induced mRNA expression of SGK1 which was paralleled by elevated protein levels and phosphorylation. The same tendency could be also detected in vivo during renal 
I/R injury. mRNA expression reached its highest level $2 \mathrm{~h}$ after reperfusion, whereas protein levels peaked $24 \mathrm{~h}$ after reperfusion. Interestingly, marked phosphorylation of SGK1 was detected only $2 \mathrm{~h}$ after reperfusion.

Binding of EPO to its receptor leads to the phosphorylation of janus kinase 2 (JAK2) which subsequently activates multiple cascades recruiting the PI3-kinase, STAT5 and MAP Kinase [22]. Furthermore, it induces the transcription of several hypoxia-related genes via the activation and nuclear translocation of the transcription factor NF- $\kappa$ B. EPO can cause increased expression of Bcl-2 and heat shock protein-70 [17], and also induces hypoxia inducible factor-1 $\alpha$ synthesis in renal I/R injury [23].

Here, we demonstrate the novel finding that EPO induces the expression and phosphorylation of SGK1. Treatment of cells with recombinant EPO resulted in a significant up-regulation of SGK1 expression both under normoxic and hypoxic conditions. Furthermore, EPO treatment in vivo led to increased SGK1 mRNA and protein expression in the kidney tissue both in sham-operated and ischemized rats. The ratio of phosphorylated and un-phosphorylated SGK1 was also higher in the EPO treated groups both under in vitro hypoxic and in vivo ischemic conditions. In vivo, we not only measured the expression of SGK1, but also performed IF staining to show the localization of the kinase and its possible relevance to the site of EPO action in the kidney. We could demonstrate that SGK1 was present and upregulated in the tubular cells which are described to be the most sensitive to ischemic injury.

This finding indicates that EPO not only regulates the expression, but also triggers the phosphorylation, thereby the activation of SGK1. Based on previous literary data, it is conceivable that activation of SGK1 by EPO might be mediated through the PI3-kinase signalling pathway.

To investigate if the EPO-induced induction and activation of SGK1 has a significant impact on the protective effect of EPO, we inhibited SGK1 expression in cells by plasmid-mediated siRNA. We showed that in those cells in which SGK1 expression was decreased, the anti-apoptotic effect of EPO was attenuated. There was an elevated release of LDH and a higher rate of apoptotic Annexin V-PI positive cells compared to EPO treated cells. All these data confirm the direct effect of EPO on SGK1 mediated protection against apoptosis.

Our data report a new signaling molecule involved in EPO cytoprotective actions, since the present study identified for the first time an important role of SGK1 in the anti-apoptotic and possibly, renoprotective effect of EPO during renal I/R injury. The EPO induced up-regulation of SGK1 was observed both under in vitro and in vivo circumstances. Moreover, in vitro, inhibition of SGK1 blocked the protective effect of EPO under hypoxia confirming a direct role of SGK1 in the EPO effect. 
These observations provide insights into a novel signaling mechanism by which EPO partly exerts its potent tissue protective actions. Given our results along with previous reports, the clinical use of EPO possibly leading to reduced cellular damage due to ischemic events should be considered, however, further investigations are needed to establish the feasibility and efficacy of EPO in clinical settings. 


\section{Acknowledgements}

This study was supported by the NNF 78846 (OTKA), TAMOP-4.2.2-08/1/KMR-2008-0004, OTKA T071730, ETT 435/2006 grants.

A. F., V. M. and AJ. Sz. are recipients of the Bolyai Scholarship. The technical assistance of Mária Bernáth is gratefully acknowledged. 


\section{TITLES AND LEGENDS TO FIGURES}

\section{Table 1. Primer pairs for RT-PCR analysis}

Table 2. Serum levels of creatinine and blood urea nitrogen (BUN) $+P<0.001$ vs. Shams $* P<0.001$ vs. I/R 24+veh.

Figure 1. Erythropoietin (EPO) prevents hypoxia-induced cell death. (A) Human embryonic kidney (HEK) cultures undergo cell death when exposed to hypoxia for $24 \mathrm{~h}$. EPO significantly abrogated cell death measured by Lactate dehydrogenase $(\mathrm{LDH})$ release in a dose-dependent manner $(* P<0.01$ vs. Hypo+veh). Inhibition of SGK1 expression by siRNA technique reduced the protective effect of EPO ( ${ }^{*} P<0.01$ vs. Hypo+EPO). (B) HEK cells undergo apoptotic cell death after exposure to 24 hhypoxia detected by Annexin V- Propidium iodid FACS analysis. Annexin V-PI -positive cells located in Q2 were considered to be apoptotic. EPO significantly ameliorated apoptotic cell death after hypoxic injury ( ${ }^{*}<0.01$ vs. Hypo+EPO), whereas inhibition of SGK1 expression by siRNA abolished the anti-apoptotic effect of EPO $(* P<0.01$ vs. Hypo+EPO)

Figure 2. Erythropoietin (EPO) leads to induction and activation of SGK1 both in normoxic and hypoxic Human embryonic kidney (HEK) cultures. (A) SGK1 mRNA expression was measured in normoxic and hypoxic cells with and without EPO treatment by RT-PCR. EPO treatment led to significant up-regulation of SGK1 mRNA expression both in normoxic and hypoxic cells $(* P<0.01$ vs. vehicle treated cells, respectively). (B) SGK1 protein expression was measured in normoxic and hypoxic cells with and without EPO treatment. EPO treatment led to significant up-regulation of SGK1 both in normoxic and hypoxic cells ( $* P<0.05$ vs. vehicle treated cells, respectively). EPO caused also increased phosphorylation of SGK1 in hypoxic cells, but not in normoxic cells $(* P<0.01$ vs. vehicle treated cells). PCRs and immunoblots are shown are representative of three independent experiments.

Figure 3. Effect of erythropoietin (EPO) on renal dysfunction caused by ischemia/reperfusion (I/R) injury. Serum creatinine levels (A) and blood urea nitrogen (BUN) levels (B) were measured as respective biochemical markers of glomerular dysfunction. Data represent mean \pm SD. (A) Renal I/R led to significant elevation in serum creatinine levels $24 \mathrm{~h}$ after reperfusion $(+P<0.001$ vs. Shams $)$. The increase in serum creatinine is abrogated by EPO (500 U/kg) administered intraperitoneally $24 \mathrm{~h}$ 
before induction of ischemia ( $* P<0.001$ vs. I/R $24+v e h)$. There was no difference either between shams and shams that were treated with EPO or between the animals $2 \mathrm{~h}$ after reperfusion. (B) Renal $\mathrm{I} / \mathrm{R}$ led to significant elevation in serum BUN levels $24 \mathrm{~h}$ after reperfusion $(+P<0.001 \mathrm{vs}$. Shams $)$. The elevation in serum BUN levels is abrogated by EPO (500 U/kg) administered intraperitoneally $24 \mathrm{~h}$ before induction of ischemia ( $\left.{ }^{*} P<0.001 \mathrm{vs.} \mathrm{I/R} 24+\mathrm{veh}\right)$. There was no difference in the BUN levels either between the sham-operated groups or between the animals $2 \mathrm{~h}$ after reperfusion.

Figure 4. Erythropoietin (EPO) attenuates the morphologic changes of ischemia/reperfusion (I/R) injury. (A) PAS-stained kidney sections are shown from each animal group at a magnification of 200x. I/R led to widespread degeneration of tubular architecture, tubular dilation, swelling, necrosis and apoptosis, loss of brush borders especially $24 \mathrm{~h}$ after reperfusion. (B) Figures are representative of $n=8$ for all groups. I/R led to morphologic changes in the kidney tissue $(+P<0.001$ vs. shams) EPO treatment ameliorated I/R caused histological changes $24 \mathrm{~h}$ after reperfusion $(* P<0.001 \mathrm{vs}$. I/R $24 h+v e h)$.

Figure 5. Erythropoietin (EPO) induced SGK1 mRNA and protein expression. (A) SGK1 mRNA expression was assessed by real-time PCR analysis. I/R caused elevated SGK1 mRNA expression 2 $\mathrm{h}$ after reperfusion $(\% P<0.05$ vs. shams). EPO induced SGK1 mRNA expression in all animal groups ( $* P<0.01$ vs. vehicle treated animals). $24 \mathrm{~h}$ after reperfusion, SGK1 mRNA expression was decreased compared to the $2 \mathrm{~h}$-animals in the EPO treated animals $(+P<0.01 \mathrm{vs}$. I/R $2 \mathrm{~h}+\mathrm{EPO})$. (B) SGK1 protein expression was assessed by Western blot analysis. I/R caused elevated SGK1 protein expression $24 \mathrm{~h}$ after reperfusion ( $\% P<0.05$ vs. Shams). EPO induced SGK1 protein expression in sham-operated and $2 \mathrm{~h} \mathrm{I} / \mathrm{R}$ groups $(* P<0.01$ vs. vehicle treated animals). Two and $24 \mathrm{~h}$ after reperfusion, SGK1 protein expression was decreased compared to the sham-animals in the EPO treated groups $(+P<0.01$ vs. Sham + EPO). (C) Immunofluorescent staining of the kidneys showed marked SGK1 expression located in the tubuli. Up-regulated total SGK1 (green fluorescence) (left panel) and phosphorylated-SGK1 (SGK1-P, red fluorescence) were stained in EPO treated animals in the sham-operated group and $2 \mathrm{~h}$ after ischemia in the tubular cells. $24 \mathrm{~h}$ after reperfusion, no marked difference was demonstrated between the vehicle and EPO treated animals. Cell nuclei were labeled with Hoechst (blue staining). 
TABLES AND FIGURES

\begin{tabular}{|c|l|c|c|}
\hline & \multicolumn{1}{|c|}{ primer pairs } & $\begin{array}{c}\text { annealing } \\
\text { temperature } \\
\left({ }^{\circ} \mathrm{C}\right)\end{array}$ & $\begin{array}{c}\text { product } \\
\text { length } \\
(\mathrm{bp})\end{array}$ \\
\hline SGK1 (human) & $\begin{array}{l}\text { Forward: 5'-CTGTGGCACGCCGGAGTATCT -3' } \\
\text { Reverse: 5'-GACGCTGGCTGTGACGAGGAC -3' }\end{array}$ & 58 & 267 \\
\hline SGK1 (rat) & $\begin{array}{l}\text { Forward: 5'-TGCTCTATGGCCTGCCTCCGTTCT-3' } \\
\text { Reverse: 5'-GTCACTGGGCCCGCTCACATTTG -3' }\end{array}$ & 59 & 476 \\
\hline GAPDH & $\begin{array}{l}\text { Forward: 5'-GGTGAAGGTCGGAGTCAACG-3' } \\
\text { Reverse: 5'-CAAAGTTGTCATGGATGACC-3' }\end{array}$ & 56 & 498 \\
\hline
\end{tabular}

Table 1.

\begin{tabular}{|c|c|c|}
\hline & $\begin{array}{c}\text { Creatinine } \\
(\mu \mathrm{M})\end{array}$ & $\begin{array}{c}\text { BUN } \\
(\mathbf{m M})\end{array}$ \\
\hline sham+veh & $53.0 \pm 2.6$ & $4.6 \pm 1.2$ \\
\hline sham+EPO & $48.8 \pm 4.1$ & $3.7 \pm 0.5$ \\
\hline IR 2h+veh & $59.5 \pm 31.8$ & $4.6 \pm 1.2$ \\
\hline IR 2h+EPO & $86.8 \pm 11.6$ & $6.3 \pm 1.2$ \\
\hline IR 24h+veh & $353.2 \pm 36.1^{+}$ & $39.3 \pm 0.4+$ \\
\hline IR 24h+EPO & $261.6 \pm 50.9^{*},+$ & $24.9 \pm 4.5^{*},+$ \\
\hline
\end{tabular}

Table 2. 


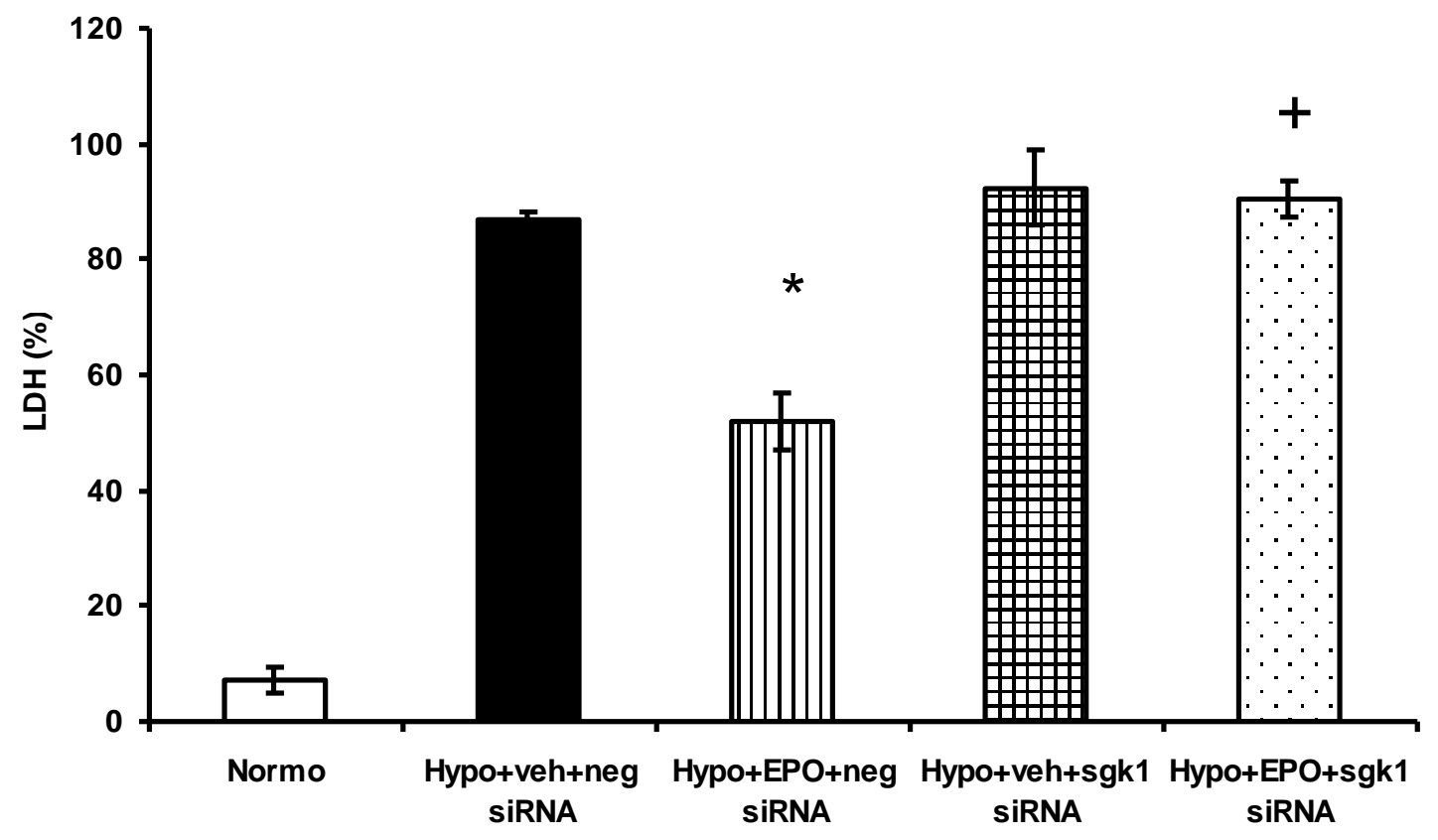

Figure 1A. 


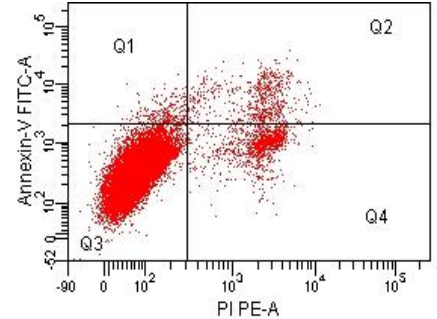

Normoxia

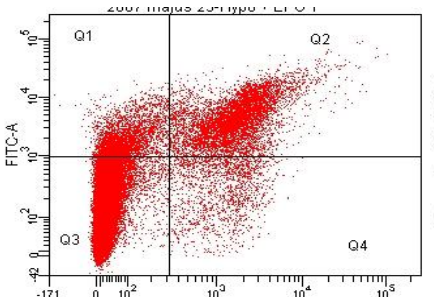

Hypo+EPO+neg siRNA

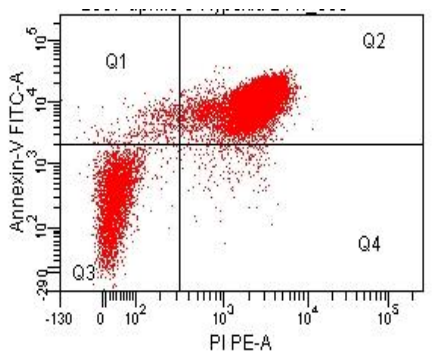

Hypo+EPO+sgk1 siRNA

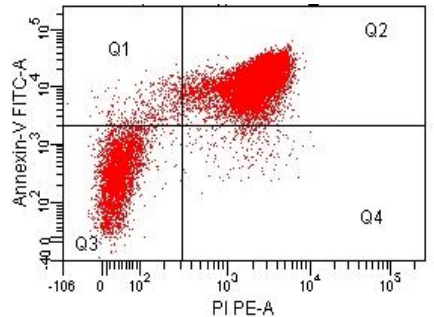

Hypo+veh+ neg siRNA

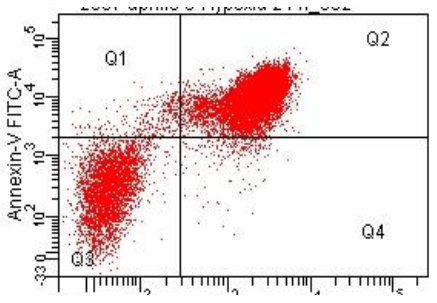

Hypo+veh+sgk1 siRNA

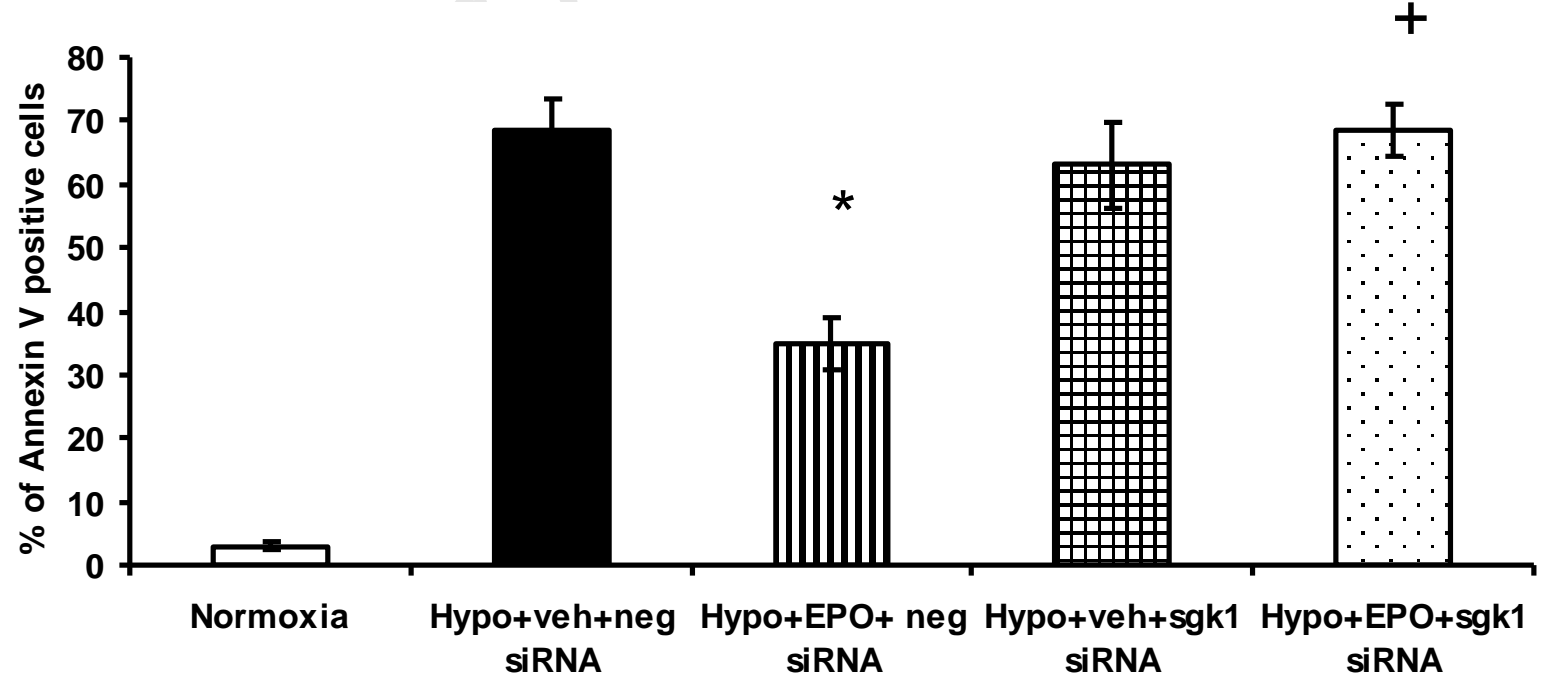

Figure 1B. 

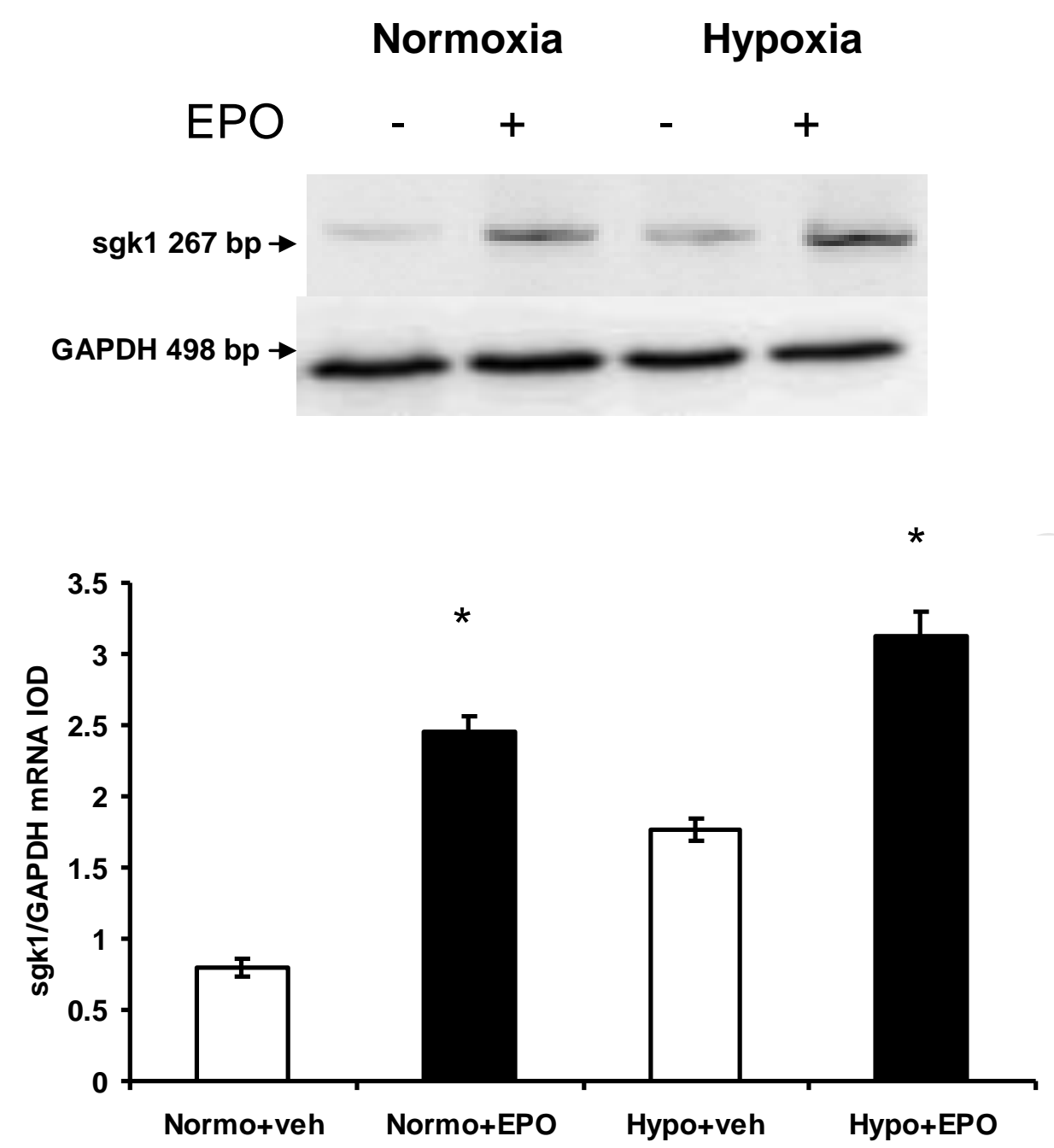

Figure 2A. 


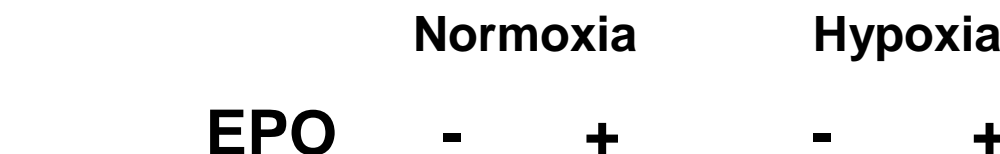

phospho-SGK1 $\rightarrow$

unphospho-SGK1 $\rightarrow$

GAPDH $\rightarrow$
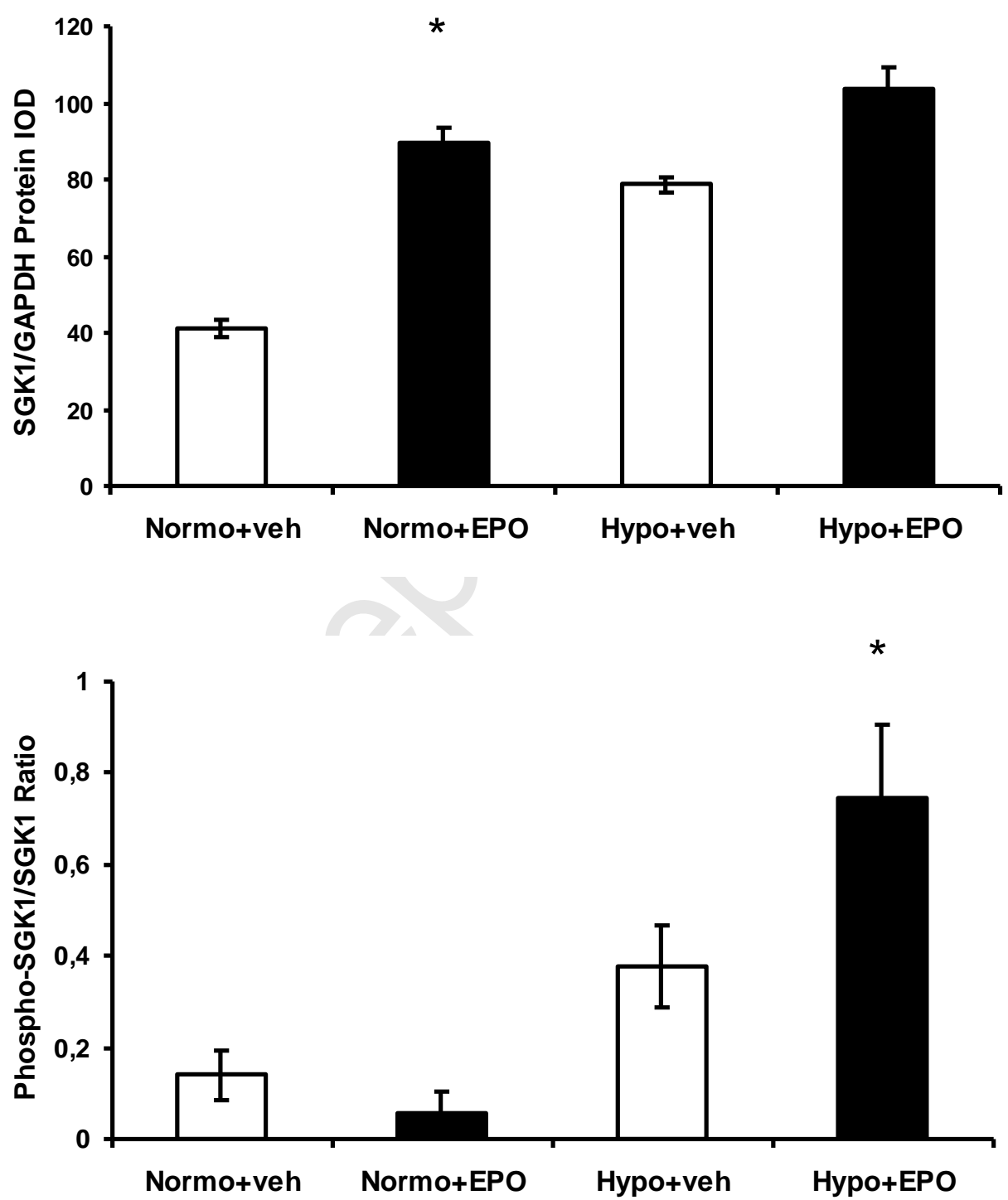

Figure 2B. 


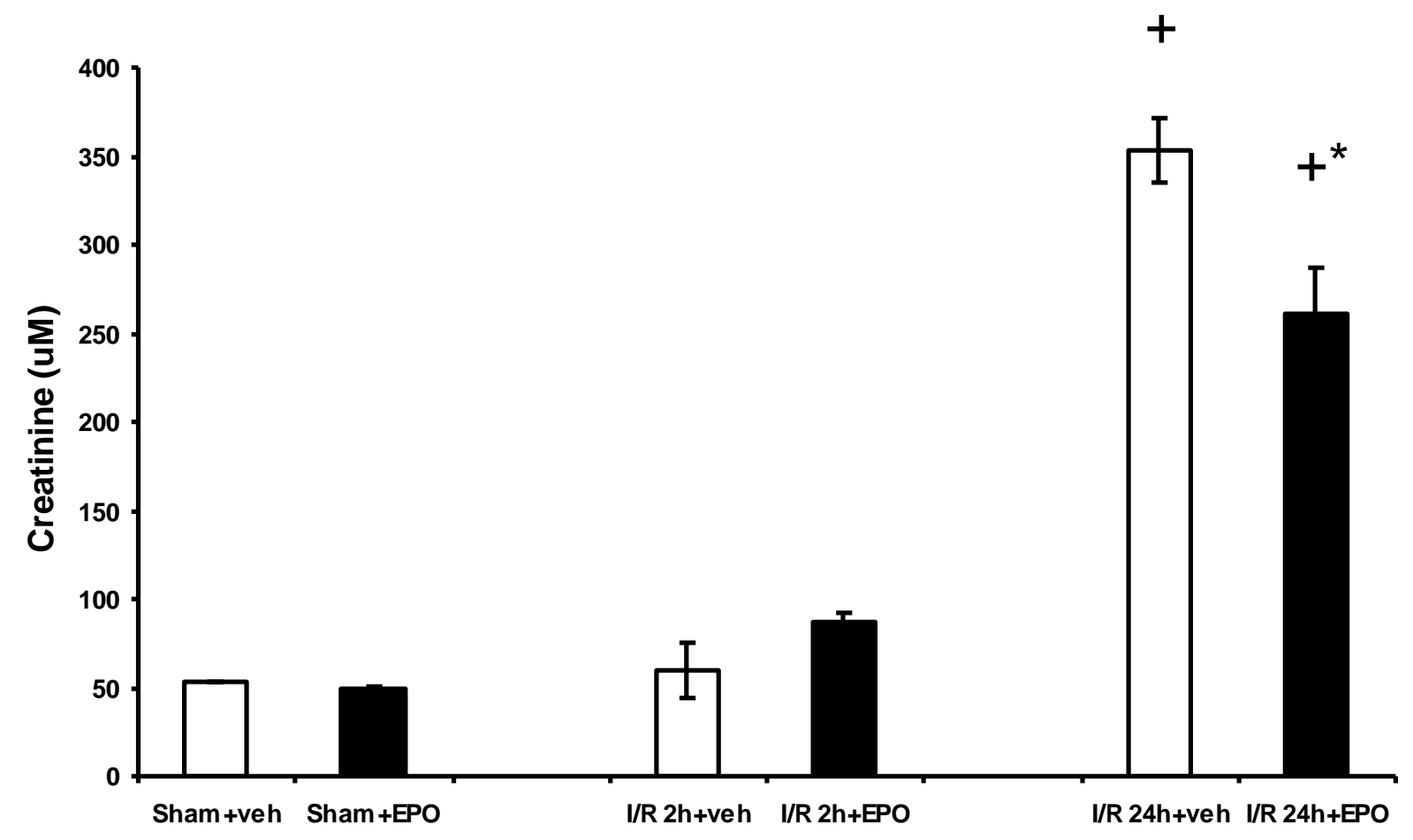

Figure 3A.

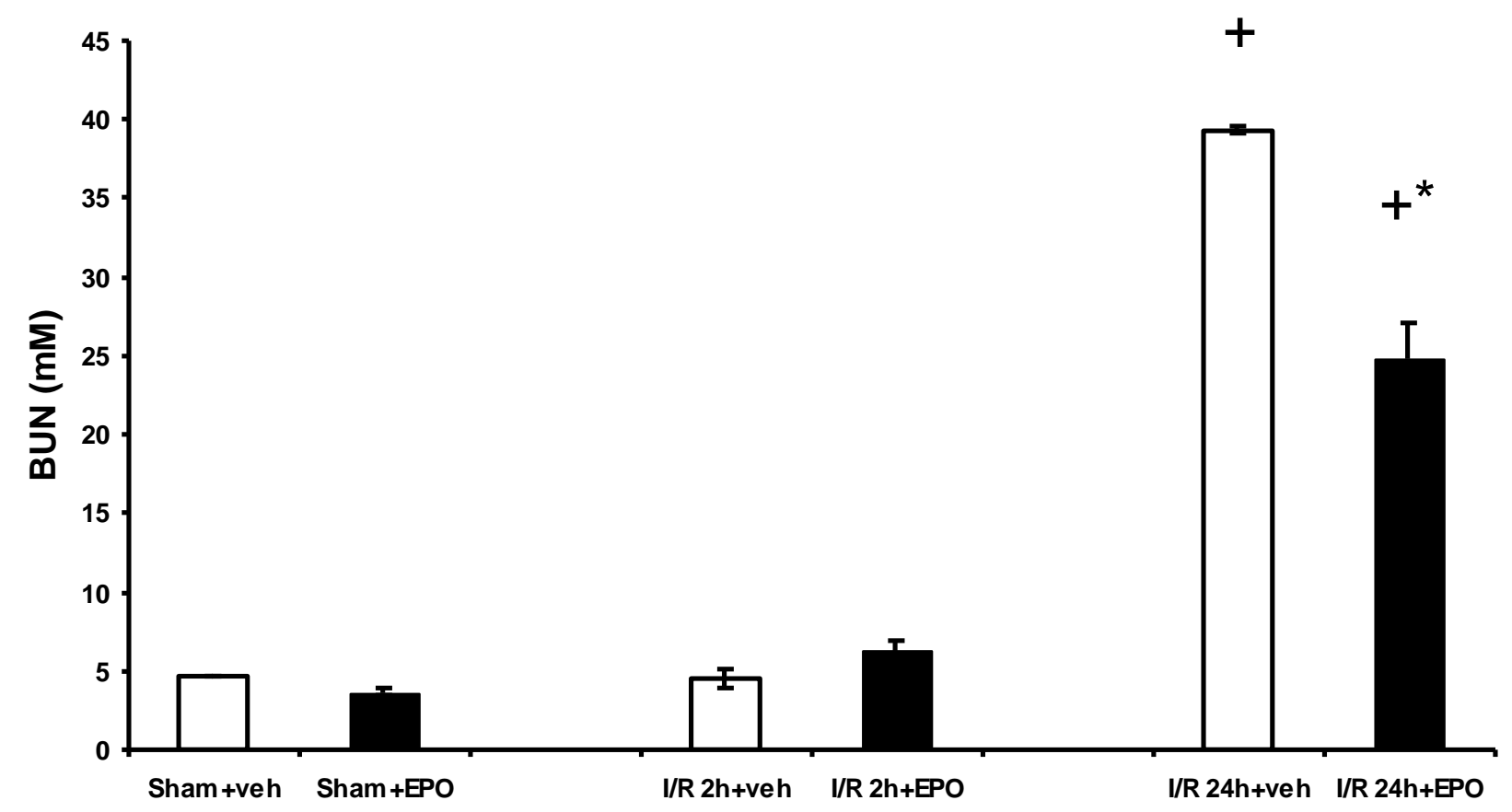

Figure 3B. 

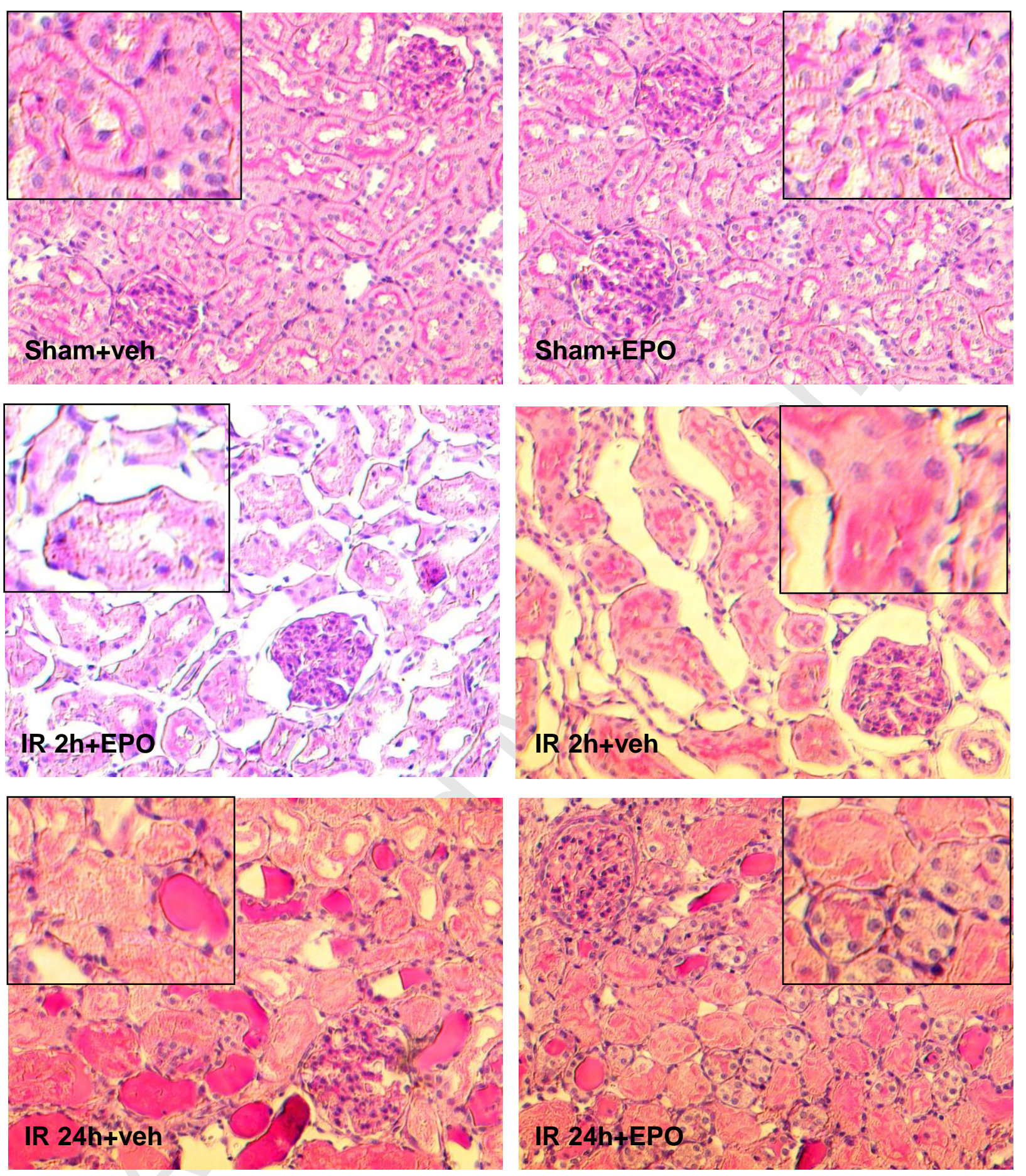

Figure 4A. 


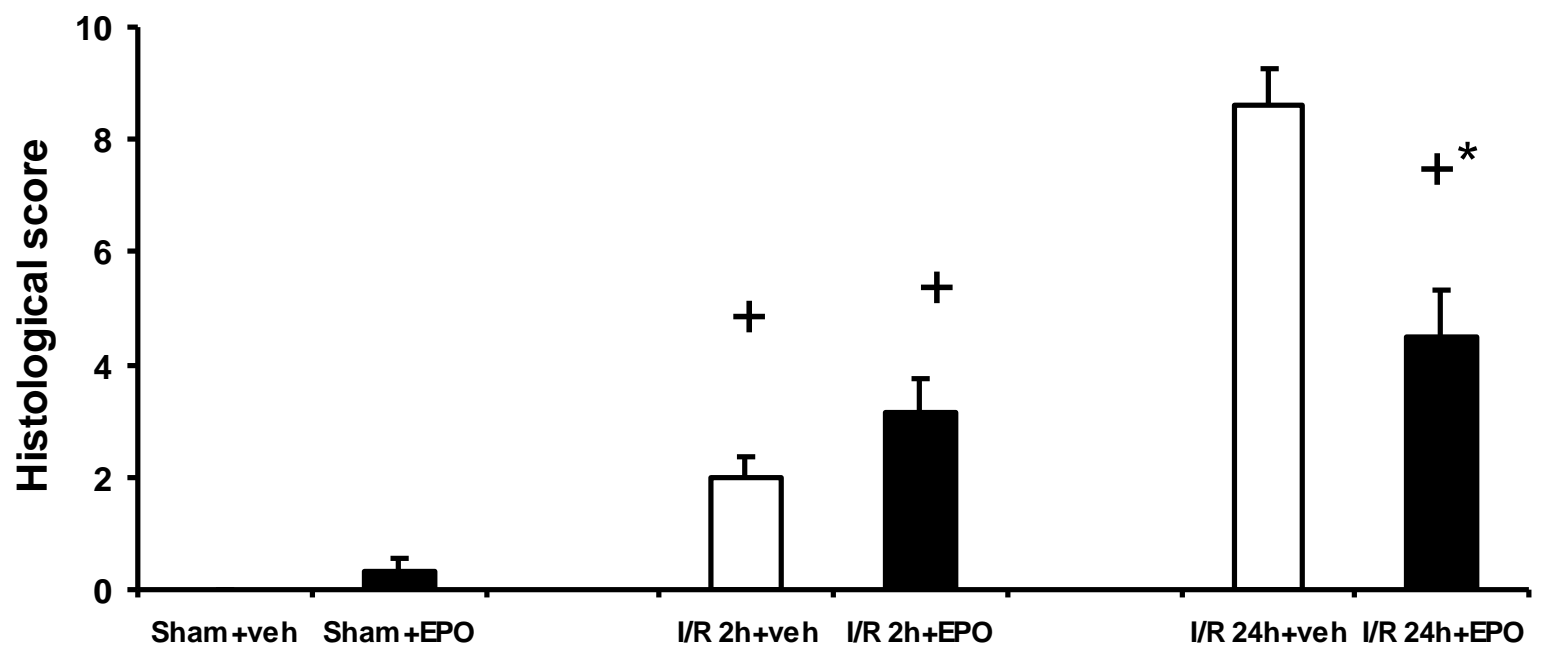

Figure 4B.

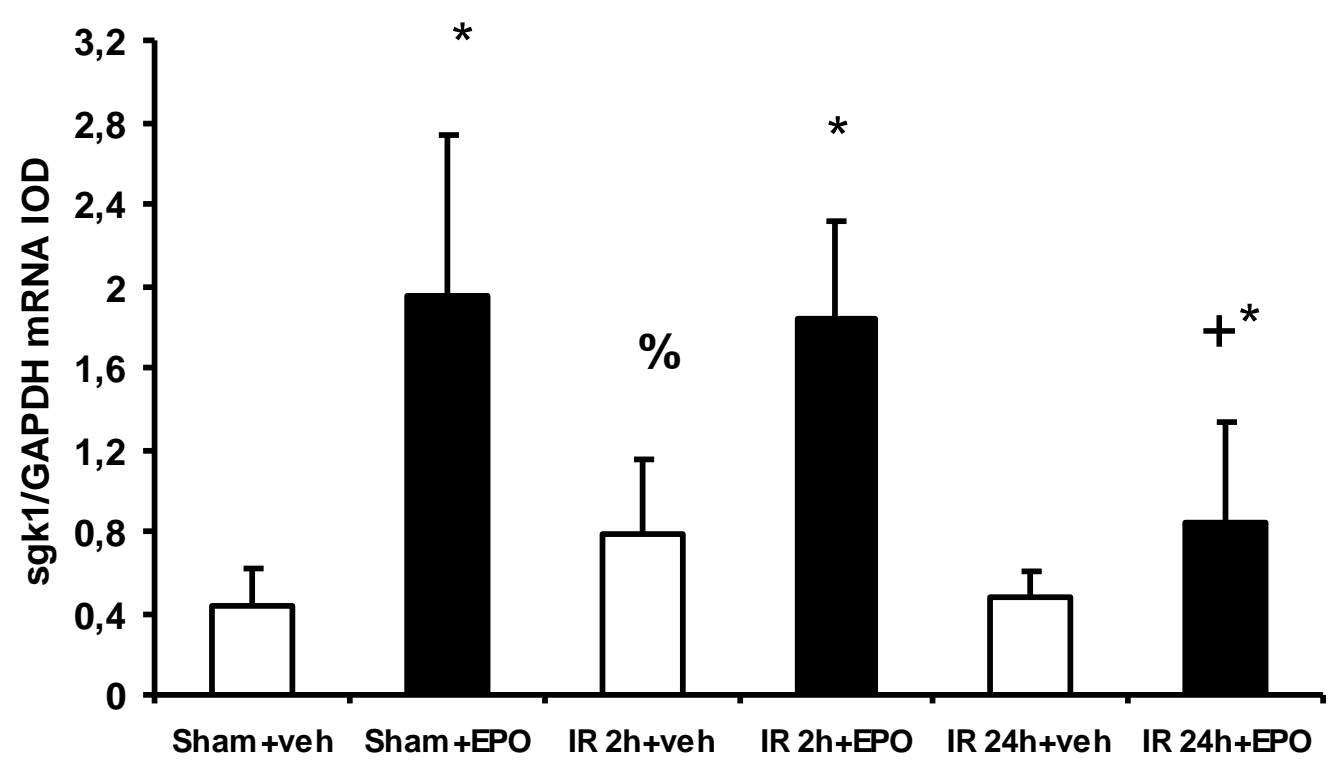

Figure 5A. 
phospho-SGK1

unphospho-SGK1

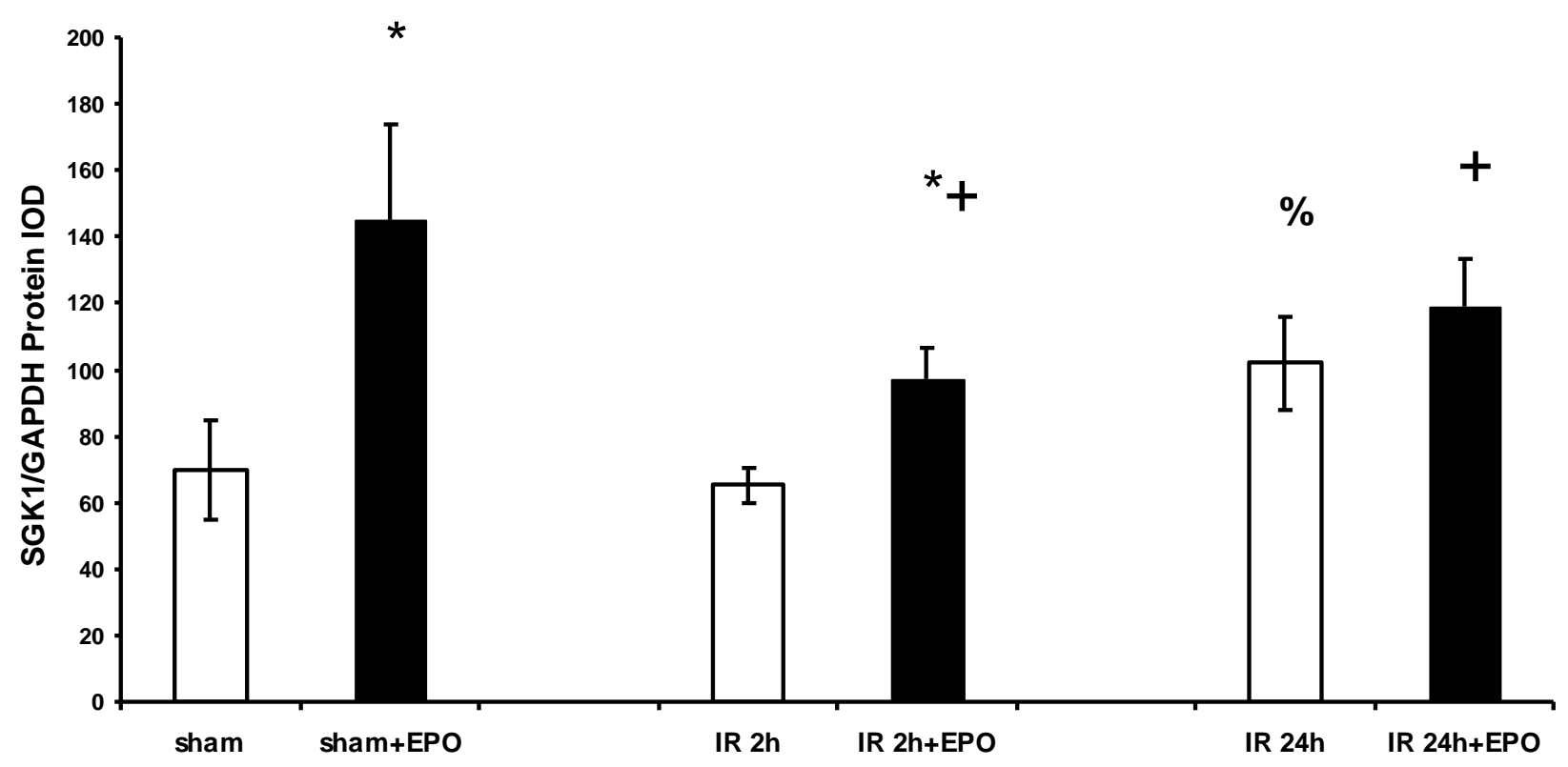

Figure 5B. 
Sham+veh
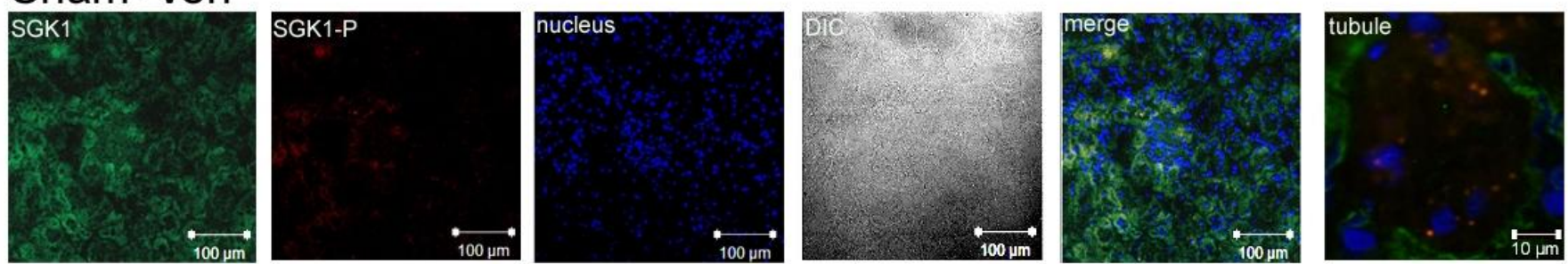

Sham+EPO
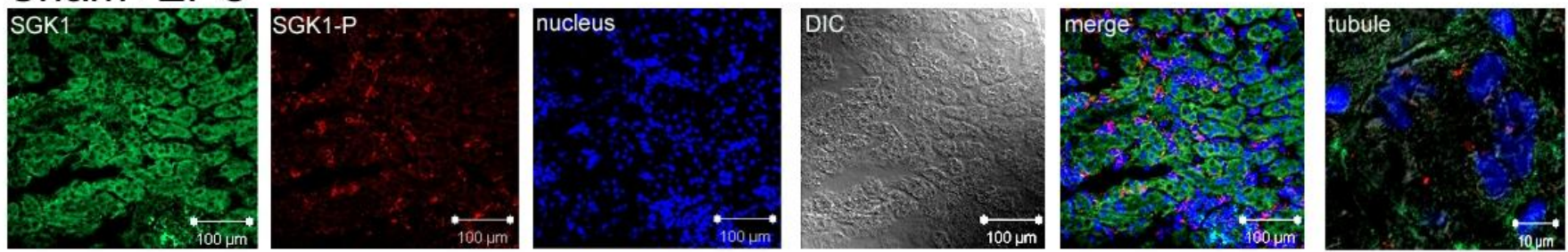

IR $2 h+v e h$
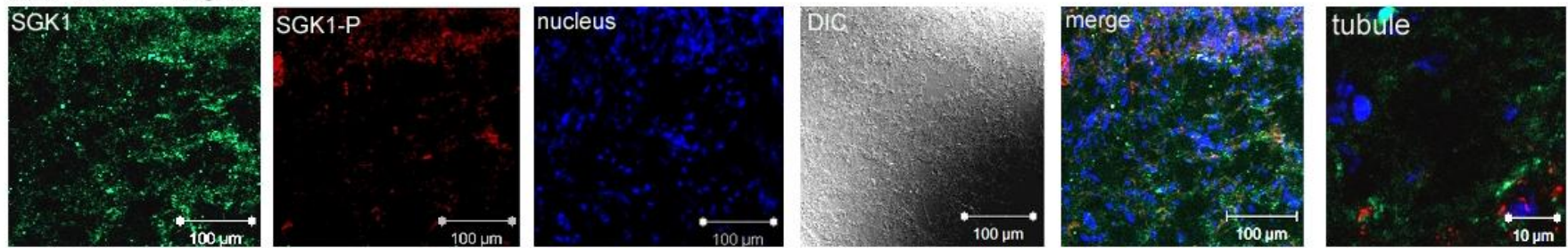

IR $2 \mathrm{~h}+\mathrm{EPO}$
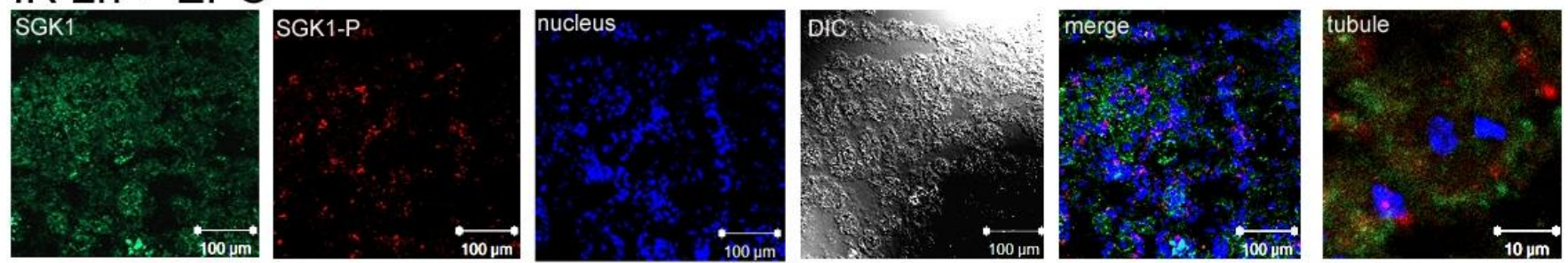

IR $24 \mathrm{~h}+$ veh
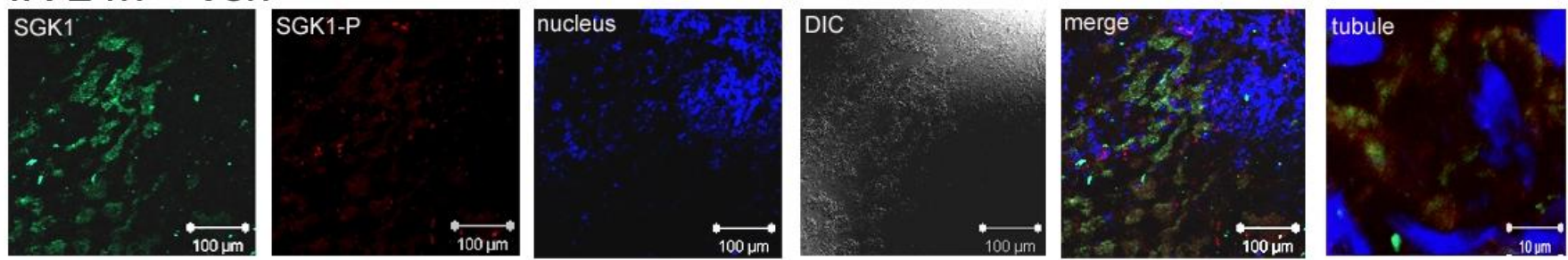

IR $24 h+$ EPO
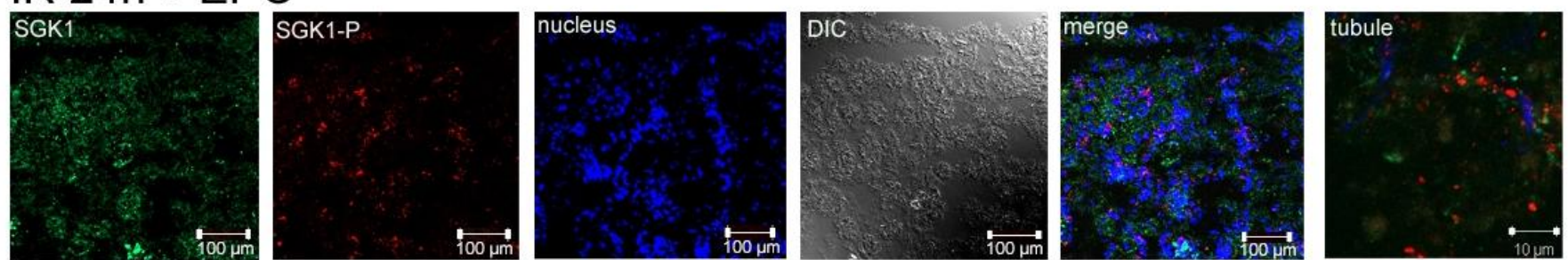

Figure 5C. 


\section{REFERENCES}

[1] Krantz SB. Erythropoietin. Blood. 1991;77:419-34. Review.

[2] Lacombe C, Mayeux P. Biology of erythropoietin. Haematologica. 1998;83:724-32. Review.

[3] Brines ML, Ghezzi P, Keenan S, Agnello D, de Lanerolle NC, Cerami C, Itri LM, Cerami A. Erythropoietin crosses the blood-brain barrier to protect against experimental brain injury. Proc Natl Acad Sci U S A. 2000;97:10526-31.

[4] Sirén AL, Fratelli M, Brines M, Goemans C, Casagrande S, Lewczuk P, Keenan S, Gleiter C, Pasquali C, Capobianco A, Mennini T, Heumann R, Cerami A, Ehrenreich H, Ghezzi P. Erythropoietin prevents neuronal apoptosis after cerebral ischemia and metabolic stress. Proc Natl Acad Sci U S A. 2001;98:4044-9.

[5] Sharples EJ, Patel N, Brown P, Stewart K, Mota-Philipe H, Sheaff M, Kieswich J, Allen D, Harwood S, Raftery M, Thiemermann C, Yaqoob MM. Erythropoietin protects the kidney against the injury and dysfunction caused by ischemia-reperfusion. J Am Soc Nephrol. 2004;15:2115-24.

[6] Erythropoietin regulates endothelial progenitor cells. Bahlmann FH, De Groot K, Spandau JM, Landry AL, Hertel B, Duckert T, Boehm SM, Menne J, Haller H, Fliser D. Blood. 2004;103:921-6.

[7] Preconditioning with erythropoietin protects against subsequent ischemia-reperfusion injury in rat kidney. Yang CW, Li C, Jung JY, Shin SJ, Choi BS, Lim SW, Sun BK, Kim YS, Kim J, Chang YS, Bang BK. FASEB J. 2003;17:1754-5.

[8] De Broe M: Apoptosis in acute renal failure. Nephrol Dial Transplant 2001;6: 23-6.

[9] Cai Z, Semenza GL. Phosphatidylinositol-3-kinase signaling is required for erythropoietinmediated acute protection against myocardial ischemia/reperfusion injury. Circulation. 2004;109:2050-3.

[10] Zhang F, Wang S, Cao G, Gao Y, Chen J. Signal transducers and activators of transcription 5 contributes to erythropoietin-mediated neuroprotection against hippocampal neuronal death after transient global cerebral ischemia. Neurobiol Dis. 2007;25:45-53.

[11] Chong ZZ, Kang JQ, Maiese K. Erythropoietin is a novel vascular protectant through activation of Akt1 and mitochondrial modulation of cysteine proteases. Circulation. 2002;106:2973-9.

[12] Alessi DR, Deak M, Casamayor A, Caudwell FB, Morrice N, Norman DG, Gaffney P, Reese $\mathrm{CB}$, MacDougall CN, Harbison D, Ashworth A, Bownes M: 3-Phosphoinositide-dependent protein kinase-1 (PDK1): structural and functional homology with the Drosophila DSTPK61 kinase. Curr Biol 1997;7:776-89.

[13] Expression of the serum- and glucocorticoid-inducible protein kinase, Sgk, is a cell survival response to multiple types of environmental stress stimuli in mammary epithelial cells. Leong ML, Maiyar AC, Kim B, O'Keeffe BA, Firestone GL. J Biol Chem. 2003;278:5871-82. 
[14] Webster MK, Goya L, Firestone GL: Immediate-early transcriptional regulation and rapid mRNA turnover of a putative serine/threonine protein kinase. J Biol Chem 1993;268:11482-5.

[15] Leong ML, Maiyar AC, Kim B, O'Keeffe BA, Firestone GL: Expression of the serum- and glucocorticoid-inducible protein kinase, $\mathrm{Sgk}$, is a cell survival response to multiple types of environmental stress stimuli in mammary epithelial cells. J Biol Chem 2003;278:5871-82.

[16] Aoyama T, Matsui T, Novikov M, Park J, Hemmings B, Rosenzweig A: Serum and glucocorticoid-responsive kinase-1 regulates cardiomyocyte survival and hypertrophic response. Circulation 2005; 111: 1652-59.

[17] Heemann U, Szabo A, Hamar P, Muller V, Witzke O, Lutz J, Philipp T. Lipopolysaccharide pretreatment protects from renal ischemia/reperfusion injury. possible connection to an interleukin-6dependent pathway. Am J Pathol. 2000;156:287-93.

[19] Huang C, Davis G, Johns EJ: Study of the actions of human recombinant erythropoietin on rat renal haemodynamics. Clin Sci (Lond). 1992;83:453-459.

[20] Kitamura H, Isaka Y, Takabatake Y, Imamura R, Suzuki C, Takahara S, Imai E.Nonerythropoietic derivative of erythropoietin protects against tubulointerstitial injury in a unilateral ureteral obstruction model. Nephrol Dial Transplant. 2008;23:1521-8.

[21] Lang F, Böhmer C, Palmada M, Seebohm G, Strutz-Seebohm N, Vallon V. (Patho)physiological significance of the serum- and glucocorticoid-inducible kinase isoforms. Physiol Rev. 2006;86:1151-78. Review.

[22] Erythropoietin and renoprotection. Bahlmann FH, Fliser D. Curr Opin Nephrol Hypertens. 2009;18:15-20.

[23] Imamura R, Moriyama $\mathrm{T}$, Isaka $\mathrm{Y}$, Namba $\mathrm{Y}$, Ichimaru $\mathrm{N}$, Takahara S, Okuyama A. Erythropoietin protects the kidneys against ischemia reperfusion injury by activating hypoxia inducible factor-1alpha. Transplantation. 2007;83:1371-9. 